\title{
CHALLENGES FACING BANKING SUPERVISION AND ACCOUNTING IN CONTEMPORARY ECONOMIC SITUATION
}

\author{
N. Penev* \\ Department of Economics, Faculty of Economics, Trakia University, Stara Zagora, Bulgaria
}

\begin{abstract}
In recent decades there has been a dynamic process of political and economic liberalization, internationalization and globalization. Quite normally business development follows the general trend of the "opening" of markets, economic diffusion processes can be found at all levels, and the "intertwining" of national and foreign capital is considered natural course of economic development. The role of the banking sector in the development of any economy is undoubtedly important, but the whole process would not have been possible without the involvement of banks. In the light of the above, given the current economic crisis realities, given the financial sector in the creation of today's economic reality, the main goal of the study is to outline the challenges facing the banking supervision and bank accounts in relation to the sustainable development of the sector and national economy.
\end{abstract}

Key words: Accounting, Banking, Banking Supervision, Management

\section{INTRODUCTION}

Functioning of each economic system (from micro to macro level) is strongly connected with the process of investment. Contemporary structure of global economy and financial "diffusion" are directly related to foreign investment. This in turn implies the presence of economical and political stability as well as reliable banking system.

Banks have central place in the economic life of each country. They contribute to the development of economic entities and structures, they mobilize and convert significant part of financial resources into actively operating capital, make payments between companies and citizens, conduct a variety of credit, investment, insurance, trust and other operations. Banks with their operations undoubtedly stimulate innovations in the production sector, limit the unprofitable and unperspective processes and assist in achieving macro goals of the country. Banks create necessary prerequisites for establishing

\footnotetext{
*Correspondence to: Nikolai Penev Ivanov, Associate Professor, PhD,

Department of Economics, Faculty of Economics, $T$ rakia University, Stara Zagora, Bulgaria, email:penevbg@abv.bg
}

more effective relation business - state. Significant part of the financial resources of the country goes through and achieves their purposes thanks to the bank system. The bank system not only conducts cash budget implementation but also take role in covering its deficit by distribution and purchase of government securities (as they are only one method of deficit financing).

Having in mind all the above mentioned reasons, effective supervision of banking system is directly related to the financial stability of the national economy. Bulgarian National Bank (BNB) is the main body that performs banking supervision in Bulgaria. Thanks to this main function of $\mathrm{BNB}$, is conducted supervision of the credit institutions operating in the country, as well as ensuring stability of the banking and financial system. Process of implementing supervision function of BNB is subject to the principles for effective banking supervision by the Basel Committee of Banking Supervision, International Accounting standards, national legal frameworks and those ratified by the EU, etc. Implementing of effective banking supervision is strongly related to the strict bank accounting. 
The current study aims describing current problems facing bank accountancy and supervision in the context of economic crisis realities of the recent years.

Each commercial bank, operating on the territory of our country, has a license from BNB. And this is the first step of the supervising activity of the Central bank where founders, shareholders and managers should meet the criteria and conditions given by the Law of Credit Institutions (LCI) and the corresponding regulations.

The main legal basis determining the objectives, activities, tools and rules concerning the functioning of the banking system consists of a system of laws, some of which are: the Law of the Bulgarian National Bank, Law of Credit Institutions, Bank Bankruptcy Law, Law of Bank Deposit Guarantee, the Law of denomination of the Bulgarian lev (BGN), Law of Financial Collateral Act, the Law for supplementary supervision of financial conglomerates; Government Debt Act, Act for information on non-performing loans; Law against money Laundering, the Law of restriction of cash payments; the Law of Markets of Financial Instruments, the Law of consumer credit, the Law for provision of financial services at a distance; Currency Act and others. (1)

Ordinances, regulations, guidelines, rules, procedures and agreements form the normative documents. They cover basic texts relating to the regulation, the objectives and instruments of banking regulation and rules concerning the activities of credit institutions. In general they concern:

1) Licensing, approval and permissions issued by BNB for credit institutions; 2) realization of payment operations and usage of payment instruments on the territory of the country; 3) credit process and its secure; 4) the acquisition, registration, payment and trade with government securities; 5) regulations on large exposures of banks, provisioning and risk exposure, capital adequacy and liquidity, as well as their supervision; 6) internal control, regulations related to international bank account number and codes; 7) auditing, bank accounts, statistics of the balance of payments; 8) regulations relating to the Central Credit Register, the Central Depository; 9) measures against money laundering; 10) rules for formation, management and operation with Reserve Security Fund and others.
PENEVN.

Applying legal framework, observation of each of the credit institutions is connected with compiling periodic and final reports. Field inspections in banks are also conducted. Main purposes of the inspections are related to determining real financial situation, risk management of the credit activity, maintaining capital adequacy and liquidity.

Performance of effective banking supervision by BNB has a main task to ensure stability of the banking system. As a result is established a balance of the financial system of the country, monetary stability and common "trust" in the economy.

Accomplishing these goals and tasks by the banking supervision is connected with: 1) rational and safe conduct of the assets, liabilities and payment transactions on behalf of each credit institution; 2) maintaining enough capital and reserves in order to prevent negative situations in banking activity; 3) analysis, research, planning and forecasting of the processes and trends in the whole financial sector of the country; 4) outline and "counteraction" to the possible negative trends connected with transferring risk in the national financial system from other connected systems (in regard to EU membership, Monetary Counsel, ownership in the banking sector, the specifics of the Bulgarian economy, etc.).

In the management of each system, the main role is given to information. The development of reliable, accurate, complete, timely and legitimate banking information is entrusted to bank accounts - in each commercial bank (CB) and BNB. In turn the Central Bank requires from the $\mathrm{CB}$ and publishes data and analysis for the whole banking system. This is carried out every month and the separate institutions make such report once in three months. (2) ***

Above mentioned facts describe the significance of bank accountancy and bank supervision as key factors to keep the stability of the whole financial system. The beginning of the global financial crisis and the participation of bank institutions in it left many questions.

Collapse of global economy in recent years has changed the "style" of the modern bank customer and the approach of the credit institutions to him. Most adaptive commercial banks have changed their bank product offers, their policy became more flexible, but in 
compliance with the new strict regulations. Intervention on global scale of public finance and national institutions in the financial sector has led to stabilization of the banking system. Liquidity of Bulgarian banking system in last years has reached good levels. On our market there is not a single institution that went bankrupt. Nowadays the crisis for most of the economists is "the most memorable lesson in lifetime". (3)

New realities are obligatory prerequisite for change in the accountancy and supervision system of the bank institutions. A leading factor in this process is the adaptation of the national bank system to the European one. The approved legislation from 2012 and 2013 for common banking supervision by the EU will only continue the process of unification of accountancy and supervision. On the other hand independency of Bulgarian financial system decreases. To a certain extent our banking system and its two sectors commercial banks and central bank are prepared for the process "dispose of sovereign”.

The fact that Bulgaria is in the conditions of Monetary Counsel should not be disregarded. The new comes from role of the European Central Bank (ECB). It will supervise the biggest banks in the Euro zone and it will have the right to express opinion as far as control of other banks is concerned. Eventually this will be a fact after the ratification of the changes by the member states.

European Central Bank (ECB) itself is expected to be a supervisor with greater rights compared to an institution exercising monetary policy in the Euro zone. Accountancy requirements to the bank will be even greater.

Unification of bank system supervision will be followed by unification of the accountancy. (4)

Main regions where European Parliament will make changes as far as bank accountancy and supervision are concerned are $e^{\mathrm{i}}$ :

- Greater level of accountancy of the supervision, including by approval of the European Parliament to be nominated and dismissed the Chairman and Vice Chairman of the Supervisory board.

- Greater role of the national Parliaments, including organized hearing of the Chairman of the Supervisory board and its members, as well as requiring written answers from the supervision of ECB.
- Facilitated access to documents, for both Supervisory board of EU regarding banks, and European Parliament and national parliaments regarding Supervisory board.

- Attractive conditions for participation of countries outside the Euro zone which motivate as much as possible of them to get into the system in order risk of single market to be decreased.

- Clear differentiation between the team of $\mathrm{ECB}$, responsible for monetary policy and the team with supervising policy, with the aim of greater accountancy of the supervision.

- More powers for the European Banking Authority (EBA) regarding ECB and improvement of the ability to conduct stress tests and to collect information from the banks and from the national supervisory authorities. EBA will the entrusted with the unification of the functions of national supervisory authorities, while at the same time it guarantees the presence of variety in the banking system within the EU.

In this way there is a possibility gradually the significance of BNB as an important factor in Bulgaria economy to be lost. Of course more time would be needed, but the economic crisis from the recent years catalyzes this process. Bulgarian authorities should accept the greater powers, given to the European Parliament and ECB. (5)

****

Last decade has proved that pure market principles fail to regulate different corporate interests in financial and non-financial companies. Equilibrium between interests of bank shareholders and the society should be maintained. In this line of thoughts, the main role of accountancy and supervision is confirmed.

The ones who use bank accountancies shareholders, managers, personnel, the country and its institutions, creditors, investors and others, should exercise the necessary control / supervision. Each unit of the economy system should be responsible for the achieved stability.

The timely intervention of the personnel of the banking business for complying with the rules of the reasonable banking; the accurate supervision by the institutions; the attention by the investors and creditors; the moderate striving toward profit increase by the shareholders and managers; timely request for 
transparency on the part of society, all this could prevent a future financial crisis.

Management, accounting and control in recent decades were subject to private and corporate interests. In the distorted accountancy data we can find part of the reasons for the crisis. In this relation the accountancy, subjected to its main principles, not to business interests, will contribute to the stabilization of the economy. (6)

Our banking system, when included in the Euro zone will be part of the common zone for provision of financial services SEPA (Single European Payment Area. SEPA - Single Euro Payment Area. SEPA includes all member states of the EU, Island, Lichtenstein, Norway, Switzerland and Monaco). SEPA aims creation of single market of payment products and services in Euro. This process implies some harmonized rules, standards and procedures. Project SEPA includes:

- Common currency - Euro;

- a single set of payment instruments in Euro - credit transfers, direct debits and payment cards;

- infrastructure for processing payments in euro;

- common technical standards and business practices;

- harmonized legal framework;

- innovative services to meet the needs of the payment service users.

SEPA is a challenge facing accountancy and supervision of the countries of the community. Processes related to the creation of SEPA will influence Bulgarian banks after introduction of Euro in our country. Most of them are already implemented - usage of IBAN and BIC to determine customers' and banks' accounts; common procedures for electronic data processing and messages in the payment system; regulation of information according to ISO 20022; harmonization of the legal framework; regulation of the obligations and rights of participants in payments, etc.(7)

SEPA, TARGET2 (Trans-European Automated Real-time Gross settlement Express Transfer system.), regulations of the Basel Committee on Banking Supervision, the EC directives, etc., and their ratification by the country, affect the organization and technology of the accountancy in credit institutions. System of accounting and transfer of information through networks is in the basis of contemporary bank payments. Standardization and unification in the socio-economic life requires changes and harmonization of the accountancy. Transnationality of the business leads to the introduction of uniform rules and accountability follows the overall development trend.

Changes in Bulgarian accountancy legislation follow the changes imposed by the membership in EU. To summarize, as far as banking accountancy and supervision is concerned, to a great extent uniformity in the interpretation of accounting information and documents relating to operations (active, passive and payment) has been achieved in banking sector in our country. Standardization and operational compatibility in nowadays situation should correspond with the stability of the sector, one of the significant features of the banking. Achieving unification hides negative sides and instability, related breakthrough system based on information systems (e.g. card payments). Having this in mind, we can outline another challenge facing accounting and supervision in contemporary banking accountancy. (8)

\section{CONCLUSION}

In conclusion despite public negative attitude towards banks, increased in recent years, proper functioning of the economic system without them is not possible. The outlined facts in the survey describe the significance of the accountancy and supervision in the activities of the contemporary credit institutions. Therefore effective accountancy and supervision are the basis for the prosperity of the entire financial system and the sustainable development of the global economy.

The author is grateful to the National Science Program "Healthy Foods for a Strong BioEconomy and Quality of Life", FP 4.3. A new generation of value-added bio-based chains, funded by the Ministry of Education and Science.

\section{REFRENCES}

1. Nenova, R., Agricultural holdings - a new manifestation of social agriculture, Dimitar A. Tsenov Academy of Economics Svishtov, Narodnostopanski Archives, 2014, pp 55-70.

2. Nenova, R., Monitoring of agricultural greenhouse gases, Dimitar A. Tsenov Academy of Economics - Svishtov, Narodnostopanski Archives, 2015, pp 7090. 
3. Georgieva, E. Legal regulations in support of the agricultural producers in Bulgaria. Plovdiv, Scientifics works, vol. LVI, 2012, Academic Publishing House of Agricultural University Plovdiv, ISSN 1312-6318-4, p.227-232.

4. Georgieva, E. Options for reporting of depreciation of fixed biological assets according to IAS 41 Agriculture. Electronic journal "Economics and computer science",Volume 2, 2016, ISSN 23677791, Varna, Bulgaria, p.15-22.

5. Georgieva, E., Penev, N. Accounting for the depreciation of the vineyards and its impact on the taxation of the enterprise, International scientific-practical conference "Possibilities for business development economic, management and social dimensions", Svishtov, 2018, v. 1, ISBN 978-954-23-1702-9, p.351-358.

6. Georgieva, E. Penev, N. Accounting opportunities for depreciation of a cow herd. Trakia Journal of Sciences, ISSN 1313-7069/ Volume 15, 2017. Series Social Sciences/p. 223-228.

7. Perkov, V., Classification of European countries by the level of business-tobusiness e-commerce development, Dimitar A. Tsenov Academy of Economics Svishtov, Yearbook, 2016, pp 241-277.

8. Nenova, R., Methodological differences in the environmental footprint, Dimitar A. Tsenov Academy of Economics - Svishtov, Almanac scientific research, Vol. 24, 2017, Part II., pp 179-205. 